\title{
Study on hospital responsibilities regarding the completeness of medical resumes
}

\author{
Suyoko ${ }^{1}$, Retno Astuti Setijaningsih ${ }^{1}$ and Slamet Isworo ${ }^{2, *}$ \\ ${ }^{1}$ Department of Medical Record, Faculty of Health, Dian Nuswantoro University, Semarang, Indonesia. \\ 2 Department of Environmental Health, Faculty of Health, Dian Nuswantoro University, Semarang, Indonesia.
}

Magna Scientia Advanced Biology and Pharmacy, 2021, 01(02), 021-031

Publication history: Received on 09 January 2021; revised on 16 January 2021; accepted on 19 January 2021

Article DOI: https://doi.org/10.30574/msabp.2021.1.2.0004

\begin{abstract}
Objective: Hospitals are legally responsible for the excellent service quality provided to patients based on statutory provisions. Hospital responsibilities in health services include criminal, civil and administrative liability. This study aims to determine the responsibility of the hospital in documenting medical resumes.

Methods: The research method used is literature review, through review of research journals related to the completeness of medical resumes that have been published on accredited journal platforms in 2010-2020. This research was conducted in August-October 2020.

Results: Analysis of 20 research journals relating to the completeness of medical resumes in the reviewed hospitals, it is known that the completeness of medical resume documents in the hospital is on average $75.80 \%$ Only 2 hospitals out of 20 hospitals documented medical resumes in accordance with the minimum hospital service standards. Based on the prevailing laws and regulations, the hospital is not criminally responsible for the incomplete documentation of medical resume, but the hospital is responsible civilian based on the principle of representative responsibility and administratively.

Conclusion: The hospital has not optimally documented medical resumes in accordance with the minimum hospital service standards. As a result, the hospital is both civilly and administratively liable. Supervision of the doctor's performance in documenting medical resumes and the role of the medical record committee in ensuring medical staff complete all medical records of patients served is required.
\end{abstract}

Keywords: Hospital Responsibility; Medical Record Document; Completeness; Medical Resume

\section{Introduction}

Hospital is a health service institution providing complete individual health services for inpatient, outpatient and emergency services. In carrying out its functions, the hospital has an obligation to document the medical records [1]. The definition of medical records in the Regulation of the Minister of Health Number 269 of 2008 concerning Medical Records is "Files containing notes and documents regarding patient identity, examination, treatment, actions and other services having been provided to patients"[2].

Hospitals are legally responsible for the quality of care provided to patients. The hospital responsibility in the patient care and the documentation of patient medical records is delegated to doctors, nurses and health care professionals[3]. The doctor's responsibility is stated in Article 46 paragraph 1 and paragraph 2 of Law Number 29 of 2004 concerning Medical Practice. What stated in the paragraph (1) is that every doctor or dentist in carrying out medical practice is

\footnotetext{
${ }^{*}$ Corresponding author: Slamet Isworo

Department of Environmental Health, Faculty of Health, Dian Nuswantoro University, Semarang, Indonesia. 
obliged to document medical records, and in the paragraph (2), it stated that medical records as referred to the paragraph (1) must be completed immediately after the patient has received health services [4].

Medical records are documents as evidence of all service actions, disease progression and treatment during a patient's visit or hospitalization [5]. Data and information in medical records can be used for health care and treatment of patients, evidence in the process of law enforcement, medical and dental disciplines and enforcement of medical and dental ethics, educational research purposes, basic health service fee payers and health statistical data"[2].

Proper documented medical records will be able to support hospitals, doctors, health workers as legal protection in case of medical disputes, however, improper documented medical records can affect the quality of services at the hospital and also cause harm to hospitals, doctors and health personnel involved because it cannot provide convincing evidence for the services having been provided to patients.

The contents of the medical record are the property of the patient. Therefore, the patient possesses the right to obtain the contents of the medical record. This right is as stated in Article 8 of Law Number 36 of 2009 concerning Health, stating that "Every person has the right to obtain information about his/her health data, including actions and treatments that have been or will be received from health practitioners"[6]. The same regulation is also regulated in Article 17 paragraph (3) of the Regulation of the Minister of Health Number 4 of 2018 concerning Hospital and Patient Obligations. It states that patient rights include access to the contents of medical records. The contents of the medical record that the patient is entitled to are in the form of a summary of the medical record. The summary of medical records can be given, recorded, copied by the patient or those who are authorized or with the written consent of the patient or the patient's family entitled to do so[2].

As a consequence of fulfilling the patient's rights in Article 29 paragraph (1) letter (m) of Law Number 44 of 2009 concerning Hospitals, hospitals have an obligation to respect and protect patient rights. To fulfill the patient's right to a summary of the medical record, in carrying out medical practice, the doctor must document the comprehensive results of the services provided in the medical record. However, in health services practice, there are still problems and obstacles, in which medical records are documented incompletely and unclearly; and medical records aren't documented on time [7].

Based on the aforementioned background, this study aims at examining the responsibility of the hospital for documenting medical resumes. These issues are reviewed based on the applicable legal regulations/laws in Indonesia. This research is expected being able to be an input for the hospital in understanding its responsibility for medical records.

\section{Methods}

This research is literature review research, in which this research reviews research journals examining the completeness of medical resume documentation. The journals reviewed are journals published in accredited journals platform in the 2010-2020. This research was conducted in August-October 2020. Data is collected and reduced according to the information required.

The research data were then analyzed descriptively and qualitatively with a normative juridical approach, "which is an analysis that explains or describes the applicable regulations, then linked to the reality that occurs in society, and finally conclusions are drawn"[8]. The regulations used are the regulations in Indonesia governing the hospital's responsibility for completing medical resumes.

\section{Results}

\subsection{Screening process for the selection of research results}

The screening process and the selection of research results are analyzed and summarized in Figure 1. In this screening process, the results of the research selected are research examining the completeness of medical resume documentation or other terms, namely discharge summary. 


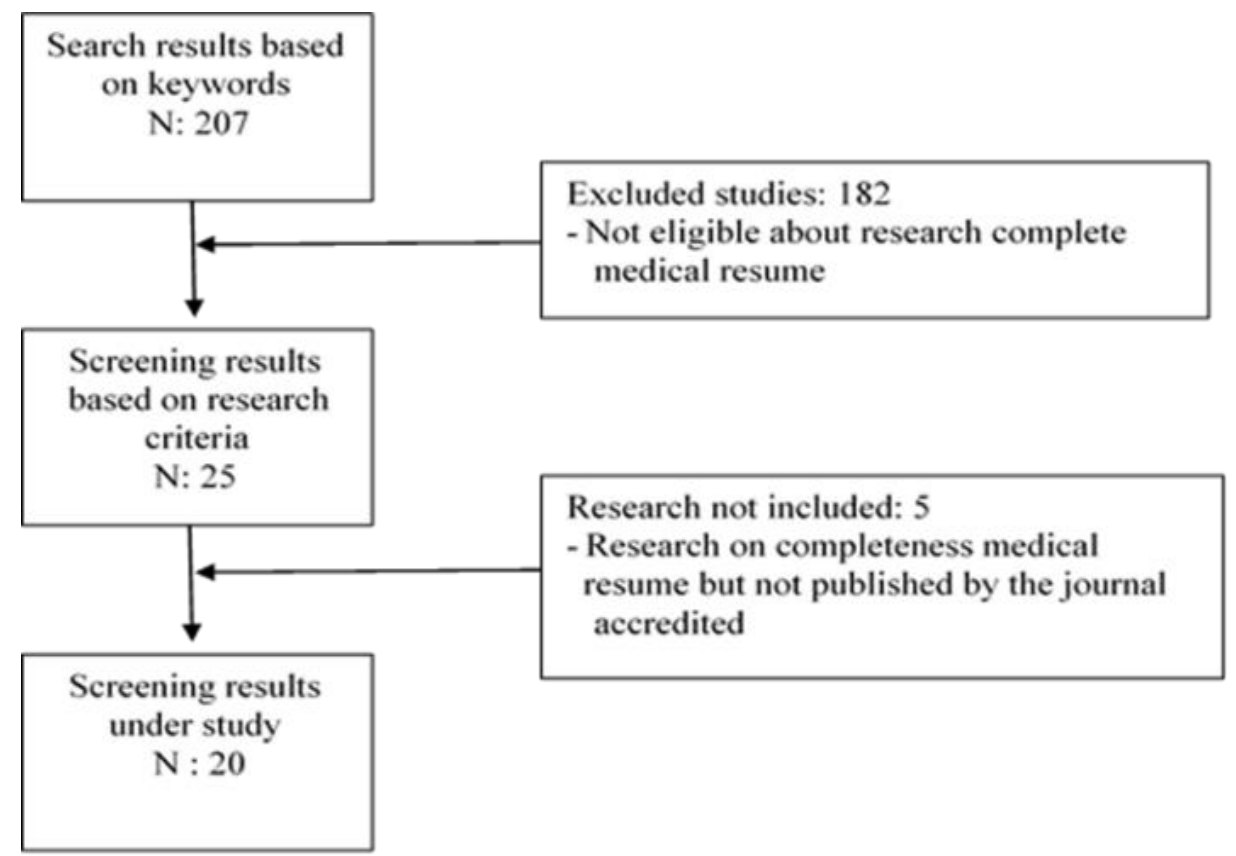

Figure 1 Screening process for the selection of research results.

\subsection{Summary of screening results}

From the screening process of research results in Figure 1 regarding the completeness of medical resumes, it was found that the research results meeting the criteria to be seen were 20 research results. Summary of research results can be seen as follows.

Table 1 Summary of screening results

\begin{tabular}{|c|c|c|c|}
\hline Reference & Sample & $\begin{array}{l}\text { Research } \\
\text { Year }\end{array}$ & Results \\
\hline $\begin{array}{l}\text { Purwanti et al., } \\
2019 \text { [9] }\end{array}$ & 103 & 2017 & The completeness of the 100 samples is $100 \%$ complete \\
\hline $\begin{array}{l}\text { Sugiyanto et al., } \\
2018[10]\end{array}$ & 100 & 2015 & $\begin{array}{l}\text { Completeness of the } 100 \text { samples was from the review of } \\
\text { identification: } 82.3 \% \text {, the review of important reports : } 25.5 \% \text {, the } \\
\text { review of authentication : } 54.7 \% \text { and the review of recording : } 35 \%\end{array}$ \\
\hline $\begin{array}{l}\text { Devhy and Widana, } \\
2019 \text { [11] }\end{array}$ & 95 & 2019 & Completeness of the 95 samples was $100 \%$ complete \\
\hline Pratiwi, 2020 [12] & 95 & 2019 & $\begin{array}{l}\text { From } 95 \text { samples of medical records, it is known that the } \\
\text { completeness is as follows: } \\
\text { - Sign in Patient Indication: } 62 \% \text { complete, } 38 \% \text { incomplete } \\
\text { Important Physical Findings and Other Findings: } 79 \% \text { complete, } \\
21 \% \text { incomplete } \\
\text { - Diagnostic Actions and Therapeutic Procedures Having Been } \\
\text { Carried Out: } 54 \% \text { complete, } 46 \% \text { incomplete } \\
\text { - Drugs Given during Hospitalization } 64 \% \text { complete, } 36 \% \\
\text { incomplete } \\
\text { - Patient's Condition (Present Status): } 74 \% \text { complete, } 26 \% \\
\text { incomplete } \\
\text { - Summary of Containing Follow-up Instructions: } 37 \% \text { complete, } \\
63 \% \text { incomplete } \\
\text { - Summary of Discharge Patient Explained and Signed by } \\
\text { Patient/Family: } 76 \% \text { complete, } 24 \% \text { incomplete }\end{array}$ \\
\hline
\end{tabular}




\begin{tabular}{|c|c|c|c|}
\hline & & & $\begin{array}{l}\text { - Completeness of Medical Resume Form: } 60 \% \text { complete, } 40 \% \\
\text { incomplete }\end{array}$ \\
\hline Dzakiy et al., 2020 & 83 & 2018 & $\begin{array}{l}\text { The completeness of } 83 \text { medical resume samples were complete as } \\
\text { many as } 72(86.7 \%) \text { and incomplete as many as } 11(13.3 \%)\end{array}$ \\
\hline $\begin{array}{l}\text { Kartini and Liddini } \\
\text { [14] }\end{array}$ & 50 & 2019 & $\begin{array}{l}\text { Completeness of medical resumes from } 50 \text { samples were from the } \\
\text { item of patient identity: complete as many as } 43(86 \%) \text { and } \\
\text { incomplete as many as } 7(14 \%) \text {; the item of anamnese: complete as } \\
\text { many as } 44(88 \%) \text { and incomplete as many as } 6(12 \%) \text {; the item of } \\
\text { diagnosis: complete as many as } 45(90 \%) \text { and incomplete as many as } \\
5(10 \%) \text {; the item of physical examination results: complete as many } \\
\text { as } 41(82 \%) \text { and incomplete as many as } 9(18 \%) \text {; the item of } \\
\text { supporting examination results: complete as many as } 47(94 \%) \text { and } \\
\text { incomplete as many as } 3(6 \%) \text {; the item of treatment: complete as } \\
\text { many as } 47(94 \%) \text { and incomplete as many as } 3(6 \%) \text {; the item of } \\
\text { action: complete as many as } 46(92 \%) \text { and incomplete as many as } 4 \\
(8 \%) \text {; the item of doctor's name and signature: complete as many as } \\
43(86 \%) \text { and incomplete as many as } 7(14 \%) \text {. }\end{array}$ \\
\hline Lubis, 2017 [15] & 50 & 2016 & $\begin{array}{l}\text { Of the } 50 \text { medical resume samples, it was found that the completeness } \\
\text { of the item of patient's identity: complete as many as } 44(88 \%) \text { and } \\
\text { incomplete as many as } 6(12 \%) \text {; the item of medical record number: } \\
\text { complete as many as } 43(86 \%) \text { and incomplete as many as } 7(14 \%) \text {; } \\
\text { the item of history: complete as many as } 33(66 \%) \text { and incomplete as } \\
\text { many as } 17(34 \%) \text {; the item of diagnosis: complete as many as } 26 \\
(52 \%) \text { and incomplete as many as } 24(48 \%) \text {; the item of doctor's } \\
\text { name and signature: complete as many as } 35(70 \%) \text { and incomplete } \\
\text { as many as } 15(30 \%) \text {. }\end{array}$ \\
\hline Tri et al., 2019 [16] & 73 & 2019 & $\begin{array}{l}\text { Of the } 73 \text { samples of medical resumes, it was found that } 70(96 \%) \\
\text { were complete, and } 3(4 \%) \text { were incomplete. }\end{array}$ \\
\hline $\begin{array}{l}\text { Irmawan et al., } 2013 \\
\text { [17] }\end{array}$ & 123 & 2012 & $\begin{array}{l}\text { The completeness of the } 123 \text { medical resume samples is known from } \\
\text { the review of identification: complete as many as } 95(77.24 \%) \text { and } \\
\text { incomplete as many as } 28(22.76 \%) \text {; the review of important reports: } \\
\text { complete as many as } 17(13.83 \%) \text { and incomplete as many as } 106 \\
(86.17 \%) \text {; the review of authentication: complete as many as } 80 \\
(65.05 \%) \text { and incomplete as many as } 43(34.95 \%) \text {; the review of } \\
\text { proper recording: complete as many as } 123(100 \%)\end{array}$ \\
\hline $\begin{array}{lr}\text { Pratiwi } & \text { and } \\
\text { Mudayana, } & 2019 \\
\text { [18] } & \end{array}$ & 263 & 2018 & $\begin{array}{l}\text { The completeness of the } 263 \text { medical resume samples is known from } \\
\text { the review of identification: complete as many as } 263(100 \%) \text {; the } \\
\text { review of important reports: complete as many as } 150(57 \%) \text { and } \\
\text { incomplete as many as } 113(43 \%) \text {; the review of authentication: } \\
\text { complete as many as } 260(98.86 \%) \text { and incomplete as many as } 3 \\
(1.14 \%) \text {; the review of proper recording: complete as many as } 260 \\
(98.86 \%) \text { and incomplete as many as } 3(1.14 \%)\end{array}$ \\
\hline $\begin{array}{l}\text { Erlindai and } \\
\text { Nasution, 2017 [19] }\end{array}$ & 48 & 2017 & $\begin{array}{l}\text { The completeness of the } 48 \text { medical resume samples was found to be } \\
43(89.5 \%) \text { complete and } 5(10.5 \%) \text { incomplete }\end{array}$ \\
\hline $\begin{array}{l}\text { Irmawati et al., } 2018 \\
{[20]}\end{array}$ & 97 & 2017 & $\begin{array}{l}\text { The completeness of the } 97 \text { medical resume is known that the review } \\
\text { of identification: complete as many as } 60(61.86 \%) \text { and incomplete as } \\
\text { many as } 37(38.14 \%) \text {; the review of important reports: complete as } \\
\text { many as } 82(84.54 \%) \text { and incomplete as many as } 15(15.46 \%) \text {; the } \\
\text { review of authentication: complete as many as } 71(73 \%) \text { and } \\
\text { incomplete as many as } 26(27 \%) \text {; the review of proper recording: } \\
\text { complete as many as } 123(67 \%)\end{array}$ \\
\hline
\end{tabular}




\begin{tabular}{|c|c|c|c|}
\hline $\begin{array}{l}\text { Chastuti et al., } 2014 \\
{[21]}\end{array}$ & 106 & 2014 & $\begin{array}{l}\text { The completeness of the } 106 \text { medical resume is known that the } \\
\text { review of identification: complete as many as } 98(92.05 \%) \text { and } \\
\text { incomplete as many as } 8(7.95 \%) \text {; the review of important reports: } \\
\text { complete as many as } 96(90.43 \%) \text { and incomplete as many as } 10 \\
(9.57 \%) \text {; the review of authentication: complete as many as } 83 \\
(77.99 \%) \text { and incomplete as many as } 23(22.01 \%) \text {; the review of } \\
\text { proper recording: complete as many as } 89(84.23 \%) \text { and incomplete } \\
\text { as many as } 17(15.77 \%) \text {. }\end{array}$ \\
\hline Utomo, 2016 [22] & 49 & 2016 & $\begin{array}{l}\text { The completeness of the } 49 \text { medical resume samples was found to be } \\
30(61.2 \%) \text { complete and } 19(38.8 \%) \text { incomplete }\end{array}$ \\
\hline $\begin{array}{l}\text { Ani and Viatiningsih, } \\
2017[23]\end{array}$ & 102 & 2017 & $\begin{array}{l}\text { The completeness of the } 102 \text { medical resume is known that the } \\
\text { review of identification: complete as many as } 101(99 \%) \text { and } \\
\text { incomplete as many as } 1(1 \%) \text {; the review of important reports: } \\
\text { complete as many as } 78(77 \%) \text { and incomplete as many as } 24(23 \%) \text {; } \\
\text { the review of authentication: complete as many as } 78(76 \%) \text { and } \\
\text { incomplete as many as } 24(24 \%) \text {; the review of proper recording: } \\
\text { complete as many as } 71(69 \%) \text { and incomplete as many as } 31(31 \%) \text {. }\end{array}$ \\
\hline $\begin{array}{l}\text { Weningsih and } \\
\text { Kristina, } 2013 \text { [24] }\end{array}$ & 95 & 2009 & $\begin{array}{l}\text { The completeness of the } 95 \text { medical resume samples was found to be } \\
70(74 \%) \text { complete and } 25(26 \%) \text { incomplete }\end{array}$ \\
\hline $\begin{array}{l}\text { Setiawan et al., } 2020 \\
{[25]}\end{array}$ & 200 & 2019 & $\begin{array}{l}\text { The completeness of the } 200 \text { medical resume samples was found to } \\
\text { be } 175(87.5 \%) \text { complete and } 25(12.5 \%) \text { incomplete }\end{array}$ \\
\hline $\begin{array}{l}\text { Kumalasari et al., } \\
2018[26]\end{array}$ & 39 & 2018 & $\begin{array}{l}\text { The completeness of the } 39 \text { medical resume samples was found to be } \\
33(84.6 \%) \text { complete and } 6(15.4 \%) \text { incomplete }\end{array}$ \\
\hline Sukiatun, 2018 [27] & 140 & 2017 & $\begin{array}{l}\text { The completeness of the } 140 \text { medical resume samples was found to } \\
\text { be } 67(47.9 \%) \text { complete and } 73(52.1 \%) \text { incomplete }\end{array}$ \\
\hline $\begin{array}{l}\text { Fajariani et al., } 2020 \\
\text { [28] }\end{array}$ & 87 & 2020 & $\begin{array}{l}\text { The completeness of the } 87 \text { medical resume samples was found to be } \\
48(55.2 \%) \text { complete and } 39(44.8 \%) \text { incomplete }\end{array}$ \\
\hline
\end{tabular}

The results of research on the completeness of medical resumes from the results of a review of journals published in 2010-2020, it is recognized that according to the criteria of this study, there are 20 research results conducted in government hospitals and private hospitals. The results showed that the completeness of the medical resume was $75.80 \%$, while the incompleteness was $18.86 \%$. Of the 20 hospitals, there are two hospitals that have $100 \%$ documentation of medical resume, namely RSUD Sanjiwani Gianyar and RS Ganesa in Gianyar City, while 18 other hospitals have documentation of medical resume below $100 \%$.

Based on the classification of the quantitative review component, it includes the review of identification, important reporting, authentication and recording. Completeness results was obtained the review of identification of $85.49 \%$, the review of important reports of $63.80 \%$, the review of authentication of $74.38 \%$, the review of records of $74.26 \%$. The highest completeness of documentation is found in the review of identification component, while the lowest documentation is in the review of important reports. From each item review component, the incompleteness in the review of identification is in the writing of the number of medical records, name, age, gender. The incompleteness in the review of important reporting is found in Indication at admission, physical findings, diagnosis, diagnostic measures and therapeutic procedures that have been done, drugs administered during hospitalization, patient condition (present status), and follow-up instructions. The incompleteness in the review of authentication is in the incomplete writing of the name, date and signature of the doctor and the signature of the patient or family as summary evidence has been explained. The incompleteness in the review of recording is in the existence of an empty part of filling out the medical record. 
Table 2 Summary of percentage of completeness of documenting medical resumes from 20 hospitals

\begin{tabular}{|c|c|c|c|c|c|c|c|}
\hline \multirow{2}{*}{ No } & \multirow{2}{*}{ Hospital Name } & \multirow{2}{*}{$\begin{array}{l}\text { Research } \\
\text { Year }\end{array}$} & \multirow{2}{*}{$\begin{array}{l}\text { Research } \\
\text { Sample }\end{array}$} & \multicolumn{2}{|c|}{ Completeness } & \multicolumn{2}{|c|}{ Incompleteness } \\
\hline & & & & C & $\%$ & IC & $\%$ \\
\hline 1 & Sanjiwani Hospital, Gianyar & 2017 & 103 & 103 & 100 & 0 & 0 \\
\hline 2 & R.A Kartini Hospital, Jepara & 2015 & 100 & 49 & 49.4 & 51 & 50.6 \\
\hline 3 & Ganesha Hospital, Gianyar & 2019 & 95 & 95 & 100 & 0 & 0 \\
\hline 4 & dr. Soedono Hospital Madiun & 2019 & 95 & 57 & 60 & 38 & 40 \\
\hline 5 & Sumberrejo Hospital, Bojonegoro & 2018 & 83 & 72 & 86.7 & 11 & 13.3 \\
\hline 6 & Mitra Meditama Hospital & 2019 & 50 & 44.5 & 89 & 5.5 & 11 \\
\hline 7 & Imelda Pekerja Indonesia Hospital Medan & 2016 & 50 & 36 & 72 & 14 & 28 \\
\hline 8 & Delta Surya Hospital Sidoarjo & 2019 & 73 & 70 & 96 & 3 & 4 \\
\hline 9 & Ratuzalecha Hospital. Martapura & 2012 & 123 & 79 & 64 & 44 & 36 \\
\hline 10 & PKU Muhammadiyah Hospital Bantul & 2018 & 263 & 190 & 72 & 73 & 28 \\
\hline 11 & Dr. Pirngadi Hospital Medan & 2017 & 48 & 43 & 89.5 & 5 & 10.5 \\
\hline 12 & Ungaran Hospital & 2017 & 97 & 61 & 63 & 36 & 37 \\
\hline 13 & Tangerang Regency General Hospital & 2014 & 106 & 89 & 84.23 & 17 & 15.77 \\
\hline 14 & DR. Soegiri Hospital Lamongan & 2016 & 49 & 30 & 61.2 & 19 & 38.8 \\
\hline 15 & Hajj Hospital Pondok Gede Jakarta & 2017 & 102 & 82 & 80.39 & 20 & 19.61 \\
\hline 16 & Santo Yusup Hospital Bandung & 2009 & 95 & 70 & 74 & 25 & 26 \\
\hline 17 & Dharmais Cancer Hospital Jakarta & 2019 & 200 & 175 & 87.5 & 25 & 12.5 \\
\hline 18 & Aisyiyah Hospital Bojonegoro & 2018 & 39 & 33 & 84 & 6 & 15 \\
\hline 19 & dr. Iskak Hospital Tulungagung & 2017 & 140 & 67 & 47.92 & 73 & 52.1 \\
\hline 20 & City General Hospital. Makassar & 2020 & 87 & 48 & 55.2 & 39 & 44.8 \\
\hline \multicolumn{2}{|c|}{ Avearge } & & & & 75.80 & & 24.20 \\
\hline
\end{tabular}

\section{Discussion}

Hospital as a legal subject in providing health services is bound and must be responsible for all things arising as a result of the implementation of its legal position as the bearer of rights and obligations [29]. Hospital responsibility in documenting medical resumes is delegated to the doctor in charge providing direct services to patients.

Based on Article 4 of the Regulation of the Minister of Health Number 269 of 2008 concerning Medical Records, it is stated that the discharge summary must be made by the doctor or the dentist handling the patient. The contents of the discharge summary should at least include the patient's identity, admission diagnosis and indication of the patient being treated, summary of physical examination results and support, final diagnosis, treatment, follow-up, name and signature of the doctor or the dentist providing health services.

Every medical service activity must have a complete and accurate medical record for each patient; and every doctor and dentist must fill out medical records correctly, completely and on time [30]. The results showed the average completeness of documenting medical resumes was $75.80 \%$, while the incompleteness of documenting medical resumes was $24.20 \%$. According to the Decree of the Minister of Health of the Republic of Indonesia Number 129/Menkes/SK/II/2008 concerning Minimum Hospital Service Standards, it states that the standard of completing filling in medical records 24 hours after completion of service is $100 \%$. Completeness of filling out the medical record includes patient identity, history, care plan, implementation of care, follow-up and resume. 
The completeness of filling out medical resumes on average $75.80 \%$ indicates that the documentation is not yet in accordance with the minimum hospital service standards set by the government. Whereas, the purpose of making a medical resume is to ensure continuity of high-quality service if the patient is hospitalized again. It can be also to be an assessment material for medical staff to fulfill requests from official agencies or individuals like insurance companies. Moreover, it is to be given a copy to expert systems that require records of patients they have treated [31].

The incompleteness of documenting medical resumes is in accordance with what was conveyed by the Indonesian medical council that the primary problems and obstacles in the implementation of medical records are that medical records are recorded incompletely, unclearly and not on time [7]. However, the importance of medical records is to support the quality of better service provided given in health facilities, documenting incomplete medical records is exceedingly common throughout the world [32].

The results of research on documenting medical records in Iraq Basrah general hospital, During June 2016, from 268 samples of inpatients, it was found that the level of incomplete documentation reached up to 78\% [32]. The study results of the at the Referral Hospital of Menelik I, Addis Ababa, Ethiopia also demonstrated the identical thing, which is the completeness of the discharge summary of 64\%, but after intervention with inpatient health personnel training (doctors and nurses), the completeness increased to 83.8\% [33]. A study on 16 hospitals at the Hospitals of Mazandaran University of Medical Sciences in 2014 showed that the average admission of discharge summary sheets for teaching hospitals (academic medical center) was 74\% and 73\% for non-nursing hospitals [34].

Incomplete medical records, especially medical resumes, are a fundamental problem and occur in many countries. Hospitals as health service providers based on Law Number 44 of 2009 concerning Hospitals are obliged to provide the safe, quality, anti-discrimination, and effective health services by prioritizing the interests of patients in accordance with Hospital service standards [1]. For this reason, hospitals need to take seriously about documenting medical records.

Several ways can be performed by the hospital including optimizing the role of the medical record committee. Among the functions and responsibilities of the Medical Records Committee are review medical records to ensure that medical records are accurate, clinically relevant, complete and available for continuing patient care, medico-legal requirements, medical research and ensure that medical staff complete all patient medical records under care by recording discharge diagnoses and writing discharge summaries for each patient who is discharged within a certain period of time [3]. Conduct training of doctors, nurses and health workers on the importance of documenting a complete medical resume. The results of previous research at the Referral Hospital of Menelik II, Addis Ababa, Ethiopia was proven with the intervention in the form of training that can improve documentation of medical records. In addition, rewards are needed for doctors or health workers who are orderly in documenting medical resumes and vice versa, and punishment is required for doctors or health workers who are not orderly in documenting medical resumes.

The impact of inaccurate data can result in errors and adverse incidents [35]. Losses for patients or families can be in the form of physical or financial losses. For instance, a patient's illness becomes worse due to inappropriate therapy due to incomplete information, or a patient's refusal to submit an insurance claim to an insurance company.

The responsibility of the hospital for the incompleteness of documenting medical resumes in terms of criminal liability, civil liability and administrative liability are as follows

\subsection{Criminal Liability}

Criminal liability in health services by the hospital must first be proven of professional wrongdoing by health personnel in the hospital. In health service, it is called criminal malpractice. The responsibility of criminal malpractice is always individual (not corporate) and personal (only those who do it), therefore it cannot be transferred to other people or to the hospital [36].

A person that can be convicted according to the opinion of legal experts must be, at least, possess three elements, namely the act violate the written law; the act is against the law; and the act has an element of error (dolus) [29]. In documenting a medical resume, the hospital delegates to the primary doctor who handles the patient for the documentation of filling out a medical resume. Whereas, based on Article 14 of the Regulation of Minister of Health Number 268 of 2008 concerning Medical Records, hospitals, as the head of health service facilities, is responsible for securing the information contained in medical records against the possibility of loss of information or falsifying data in medical records or being used by parties who do not have the authorization. 
The results showed the level of completeness of documenting medical resumes on average was $75.80 \%$. In accordance with the principle of criminal liability, those who commit mistakes must be responsible. In Article 46 paragraph (1) and paragraph (2) of Law Number 29 of 2004 concerning Medical Practice, it states that every doctor or dentist in carrying out medical practice is obliged to make medical records (Paragraph [1]), and medical records as intended in paragraph (1) must be completed immediately after the patient has received health services (Paragraph [2]). Of these two paragraphs, it can be concluded that who are responsible for the documentation is a doctor or dentist.

If the provisions of Article 46 are unimplemented, based on the similar law, the Article 79 may be subject to criminal sanctions, namely "shall be punished with imprisonment for a maximum of 1 (one) year or a maximum fine of IDR $50,000,000.00$ (fifty million rupiah), every time, a doctor or dentist who: b. isn't intentionally making medical records as referred to in Article 46 paragraph (1)."

From the formulation of the law, it is comprehensible that those responsible for filling in medical records including medical resumes are doctors, and it is not hospitals' responsibility. However, these criminal sanctions only apply if doctors in practicing medicine do not make medical records. In the case of a doctor making a medical record but incomplete, he/she will not be subject to criminal sanctions as formulated in Article 79 of Law Number 29 of 2004 concerning the medical practice.

\subsection{Civil Liability}

The legal relationship that occurs between hospitals and patients in the perspective of civil law is a contractual relationship creating rights and obligations on each party. From various cases, civil problems occur, generally in the form of acts against the law and default. The form of default is wrong or fallacious to take health efforts, while the act of violating the law includes doing or not doing that which violates the rights of other people and is against legal obligations both to oneself or other people's objects [29].

Based on the research results, the hospital has not carried out its obligations in organizing medical records optimally. It is where the average of the completeness of medical resumes is $75.80 \%$. Based on the Decree of the Minister of Health of the Republic of Indonesia Number 129/Menkes/SK/II/2008 concerning Hospital Minimum Service Standards, the completeness of medical resumes requires completeness of completing medical records in 24 hours after completion of service is $100 \%$.

The impact of the incomplete medical resume causes harm to the patient. The law provides patients the opportunity to sue the hospital. According to Article 55 of Law Number 36 of 2009 concerning Health, it is stated that every person possesses the right to claim compensation for a person, health worker, and/or health provider who causes losses due to errors or negligence in the health services they receive. If traced further, the losses that may occur due to incomplete medical resume documentation are the responsibility of the doctor who handles the patient. It is since the responsibility for completing medical resume documentation belongs to the doctor handling the patient.

Hospitals can also be held liable under the civil code article 1367 of the Civil Code, which reads "a person is not only responsible, for losses caused by his own actions, but also for losses caused by the actions of the people who are dependent on him or due to goods under his control" [37]. The responsibility of this hospital is based on the principle of vicarious liability.

The liability of this hospital arises based on the result of mistakes made by the subordinate (employee) who works in his position as a sub-ordinate (employee) who is in charge of carrying out the hospital's obligations [36].

\subsection{Administrative Liability}

The liability of administrative law in the legal relationship between the hospital and the patient is related to policies or provisions which are the requirements for the administration of health services that must be fulfilled in the context of providing quality health services [38].

The provisions governing medical resumes are contained in Article 4 and Article 5 of the Regulation of the Minister of Health Number 269 of 2008 concerning Medical Records, stating that a discharge summary must be made by the doctor handling the patient. The contents of the discharge summary should at least include the patient's identity, admission diagnosis and indication of the patient being treated, summary of physical examination results and support, final diagnosis, treatment, follow-up, name and signature of the doctor or the dentist providing health services. Article 5 paragraph (2) states that medical records must be made promptly and completed after the patient receives service. 
The results of the study of the 20 hospitals studied were only two hospitals that had $100 \%$ documentation. Meanwhile, 18 hospitals were not in accordance with the minimum hospital service standards. The lowest completeness is in the review of the important report (63.80\%) where the incompleteness is in the indication at admission, physical findings, diagnosis, diagnostic actions and therapeutic procedures that have been performed, drugs given during hospitalization, patient condition (present status) and follow-up instructions.

Looking at the results of the research and compared with the provisions contained in the Regulation of the Minister of Health No. 268 of 2008 concerning Medical Records, it is clear that there has been a deviation or mismatch in its implementation practices. Therefore, the Minister, the head of the provincial health service, the head of the regency/city service office, can issue administrative sanctions to the hospital in the form of verbal warning, written warning, up to the revocation of the license according to their respective authority.

In addition, in Law Number 44 of 2009 concerning Hospitals, Article 29 paragraph (1) letter (o) states: "Every hospital has an obligation to respect and secure the rights of patients." Patients' rights to medical records are regulated in Article 17 paragraph (3) of the Regulation of the Minister of Health Number 4 of 2018 concerning Hospital and Patient Obligations. It states the intended right is the right to access the contents of medical records. In Article 12 paragraph (3) of the Regulation of the Minister of Health Number 268 of 2008 concerning Medical Records, the contents are in the form of a medical record summary.

Due to the violation of the hospital's obligations to Article 29 paragraph (1), the hospital may be subject to administrative sanctions in the form of: warning; written warning; or fines and revocation of hospital license."

\section{Conclusion}

Based on the research results, it can be concluded as follows:.

The hospital's responsibility for documenting medical resumes has been unimplemented according to the regulations regarding the minimum standard of hospital services. Hence, it can have an impact on the fulfillment of patient rights which are not optimal.

For criminal legal liability, the hospital is unresponsible for the incompleteness of documenting medical resumes carried out by doctors. In the scope of civil law, hospitals are responsible for actions undertaken by doctors in documenting incomplete medical resumes based on the principle of vicarious liability. In the scope of administrative law, a hospital may be subject to administrative sanctions in the form of warning, written warning; or fines and revocation of hospital licenses for not carrying out their obligations in accordance with the provisions of the Regulation of Minister of Health Number 269 of 2008 concerning Medical Records and Law Number 44 of 2009 concerning Hospitals in carrying out the obligation to fulfill patient rights.

Hospitals need paying attention to their responsibilities in carrying out their obligations in documenting medical resumes through monitoring the performance of doctors and the fellow health workers. Moreover the hospital can involve a medical record committee to help monitor compliance with medical resume documentation.

\section{Compliance with ethical standards}

\section{Acknowledgments}

The author is very grateful to the lecturers of Dian Nuswantoro University for their support, so that this research can be completed

\section{Disclosure of conflict of interest}

All authors have stated that this activity does not contain a conflict of interest

\section{Statement of ethical approval}

According to the standard guidelines for participant approval and ethical approval has been collected and preserved by the author 


\section{References}

[1] Sjaaf AC, Achadi A, Nadjib M, Ayuningtyas D, Junadi P, Kadir A, Hendrawan H. The efficiency and productivity of Public Services Hospital in Indonesia. Enfermería Clínica. 1 Oct 2020; 30: 236-9.

[2] Sidik AP, Agustina RS, Izziyana WV. Legal Protection of Medical Records for Hospital Patients. Medico Legal Update. 9 Apr 2020; 20(1): 214-7.

[3] World Health Organization. Regional Office for the Western Pacific. Medical records manual: a guide for developing countries. Manila: WHO Regional Office for the Western Pacific. 2006.

[4] Firmansyah I, Wasiska A, Marsinah R. The Implementation of Act 29/2004 Concerning Medical Practice and Its Implementation Regulations. InThe 2nd International Conference of Law, Government and Social Justice (ICOLGAS 2020) 2020 Dec 14 (pp. 85-93). Atlantis Press

[5] Anaya LS, Alsadoon A, Costadopoulos N, Prasad PW. Ethical implications of user perceptions of wearable devices. Science and engineering ethics. 1 Feb 2018; 24(1): 1-28.

[6] World Health Organization. State of health inequality: Indonesia. World Health Organization. 2017.

[7] Sudra RI. The Urgency of Regulation Regarding Standardization of Documentation in Electronic Medical Records. InThe 2nd International Conference of Law, Government and Social Justice (ICOLGAS 2020) 2020 Dec 14 (pp. 189-192). Atlantis Press.

[8] Pratama B. Indonesian legal framework to support innovation sustainability. Earth and Environment Science. Mar 2018; 126: 1-9.

[9] Purwanti IS, Prihatiningsih D, Devhy NP. Descriptive Study.The Completeness Of Medical Record Documents. JRMIK. 2020; 3(1): 36-40.

[10] Sugiyanto, Widodo, Warijan, Isnaeni R. The Complitness Analysis Quantitative Of Medical Resume Form On The Inpatient In 2015 At RSUD R.A Kartini Jepara. JRMIK. 2018; 1(1): 4-4.

[11] Devhy NP, Widana AAGO. Completeness Analysis of Inpatien Ganesha Hospital Medical Records in Gianyar City in 2019. JRMIK. 2019; 2(2): 106-110.

[12] Pratiwi RG. Overview of Completeness of Medical Resume Form With SNARS Regulation (Standar Nasional Akreditasi Rumah Sakit) RSUD dr. Soedono Madiun. Jurnal Delima Harapan. Vol 7 No 2, Sep 1, 2020v.

[13] Dzaky MN, Sudalhar, Pratama, TWY. Effect of inpatient medical resume completeness on the timeliness of BPJS claims at Sumberrejo Hospital. Jurnal Hospital Science. 2020; 4(1): 105-109.

[14] Kartini SA, Liddini H. Review of Incompleteness of Inpatient Medical Resume Writing at Mitra Medika General Hospital in 2019. Jurnal Ilmiah Perekam dan Informasi Kesehatan Imelda (JIPIKI). 2019; 4(2): 680-685.

[15] Lubis, F. Review of Incompleteness of Writing Inpatient Medical Resumes at the General Hospital of Imelda Workers Indonesia (IPI) Medan 2016. Jurnal Ilmiah Perekam Dan Informasi Kesehatan Imelda. 2017; 2(1): 229234.

[16] Tri Murni M, Ina Suhartina, Indah Dwi S. The Quantitative Analysis of Incomplete Medical Resume Completion Based on the Quality Assurance Program (A Study at Delta Surya Hospital, Sidoarjo). Jurnal Kesehatan Vokasional. 2019; 4(2): 80-89.

[17] Irmawan, Widiarta A, Hidayatullah R. Review The Completeness And Accuracy Of Resume Charging Medical Inpatients At Lungs Room In Public Service Agency Region General Hospital Ratu Zalecha Martapura Jurkessia, 4(1), 40-51.

[18] Pratiwi ND, Mudayana AA. Identification of complete medical records for patients with hyperplasia of Prostate at PKU Muhammadiyah Hospital, Bantul. Jurnal Medika Respati. 2019; 14(3): 233-244.

[19] Erlindai, Nasution, MI. Analysis of the completeness of filling in the medical record files of Ca Mammae patients who were in chemotherapy at Dr. Pirngadi Hospital Medan in 2017. Jurnal Ilmiah Perekam Dan Informasi Kesehatan Imelda. 2017; 2(2): 341-347.

[20] Irmawati, Danuri A, Sudiyono, Fauzia Rahmawati,F. Quantitative Analysis Inpatient Medical Record In Mawar Ward RSUD Ungaran. Jurnal Rekam Medis dan Informasi Kesehatan. 2018; 1(1): 11-15.

[21] Chastuti FZ, Widjaya L, Anggraini M. Analysis of factors related to the completeness of filling out medical resumes for inpatients at the General Hospital in Tangerang Regency Jurnal Inohim. 2014; 2(1): 18-29. 
[22] Utomo, AEN. Factors that influence the completeness of the medical resume of inpatients at dr. Soegiri, lamongan in Jurnal Inohim. 2016; 4(2): 63-69.

[23] Ani S, Viatiningsih W. Review of the Completeness of the Contents of Medical Records on the Medical Resume Form for Surgical Cases at Haji Hospital, Pondok Gede Jakarta in 2017. 5(1), 64-69.Indonesian of Health Information Management Journal (INOHIM). 2017; 5(1): 64-69.

[24] Weningsih IR, Kristina I. Relationship Between Completeness of Medical Resume With Accuracy of Payment of Inpatients by Health Insurance at Santo Yusup Hospital Bandung. Indonesian of Health Information Management Journal (INOHIM). 2013; 1(1): 22-28.

[25] Setiawan MY, Widjaja L, Nurmalasari M. Comparative Analysis of Completeness of Medical Records Based on Quantitative Analysis Methods with Closed Medical Record Review Analysis at "Dharmais" Cancer Hospital. Indonesian of Health Information Management Journal (INOHIM). 2020; 8(1): 1-7.

[26] Kumalasari RR, Darmawan Y, Winarni S. Relationship of Knowledge, Attitude and Age of Doctors Against Completeness of Filling in Medical Record Files in Bpjs Patients at Aisyiyah Hospital. Bojonegoro. Jurnal Kesehatan Masyarakat. 2018; 6(4): 125-131.

[27] Sukiatun. Analysis Claim Bpjs Review From Completeness Of Medical Record Documents And Accuracy Diagnosis Codes In RSUD. dr. Iskak Tulungagung. Journal for Quality in Public Health. 2018; 1(1): 1-12.

[28] Fajariani V, Noor NB, Amqam H. Completeness Analysis of Completeness Filling and Time of Returning The Medical Record for Inpatient Patients at Regional General Hospital of Makassar City. Journal of Asian Multicultural Research for Medical and Health Science Study. 2020; 1(2): 74-83.

[29] Yustina Endang Wahyati, Get to know Hospital Law, CV Keni Media, Bandung. 2012.

[30] Ida Sugiarti. Legal Protection of Patient Rights to Completeness and Confidentiality in Management of Medical Record Documents. Advances in Health Sciences Research, volume 26 2nd Bakti Tunas Husada-Health Science International Conference (BTH-HSIC 2019)

[31] Depkes RI Direktorat Jenderal Bina Pelayanan Medik. Guidelines for Implementation and Procedure of Hospital Medical Records in Indonesia Revision II. Jakarta. 2006.

[32] Mahmoud, Rajaa, Hussein, Riyadh, Al-Hamadi, Nihad, Saihoud, Shabeeb, Majeed, Atared. Assessment of the documentation completeness level of the medical records in Basrah General Hospital. 2018; 36: 50-59.

[33] Tola K, Abebe H, Gebremariam Y, Jikamo B. Improving completeness of inpatient medical records in Menelik II referral hospital, Addis Ababa, Ethiopia. Advances in Public Health. 2017 Jan 1;2017

[34] Benyamin Mohseni Saravi, Zolaykha Asgari, Hasan Siamian, Ebrahim Bagherian Farahabadi, Alimorad Heidari Gorji, Nima Motamed, Mohammad Fallahkharyeki , Ramin Mohammadi." Documentation of Medical Records in Hospitals of Mazandaran University of Medical Sciences in 2014: a Quantitative Study", Acta Inform Med. JUN 2016; 24(3): 202-206.

[35] Amal H. Alghamdi, Adel M, Ibrahim, Waqar A, Asrar, Khaled Alsharef, Mohammad H. Alshehri. Assessment of the completeness and quality of medical records used in the primary health care centers: case study in Jeddah, Western Region,Saudi Arabia. International Journal of Academic Research Part A; 2014; 6(4): 60-64.

[36] Dahlan Sofyan. Health law signpost for the medical profession, Universitas Diponegoro, Semarang. 2005.

[37] Azhari, Reyhan Nabillah. Understanding the Contents of Indonesian Civil Law.263. 2020

[38] Prasada MY, Mudana IY. Hospital Responsibilities for the Confidentiality of Medical Records. Kertha Semaya. 2014; 2(2): 1-6. 